\title{
Evaluation of the Effects of Melatonin Supplementation on the Physical and Physiological Performance Following Total Night Sleep Deprivation in Trained Young Males
}

\section{Eğitimli Genç Erkeklerde Toplam Gece Uyku Yoksunluğunu Takiben Melatonin Desteğinin Fiziksel ve Fizyolojik Performans Üzerindeki Etkilerinin Değerlendirilmesi}

\author{
(1) Eisa Khaleghi-Mamaghani, (1) Farhad Rahmani-Nia, (1) Hamid Arazi \\ University of Guilan Faculty of Sport Sciences, Department of Exercise Physiology, Rasht, Guilan, Iran
}

\begin{abstract}
Objective: This study aims to evaluate the effects of melatonin supplementation on the physical and physiological performance following total night sleep deprivation in trained young males.

Materials and Methods: Ten trained young males (23.4 \pm 1.71 years, $23.96 \pm 1.63 \mathrm{~kg} / \mathrm{m}^{2}$ ) participated in four sessions (sessions 1 and 2 nightly habitual sleep; sessions 3 and 4, total night sleep deprivation). Then, using the double-blind design, subjects were divided into two groups of who took melatonin supplement $(10 \mathrm{mg})$ and placebo, respectively. The subjects were tested by the implementation of the sleep protocol. Then, they consumed the supplement and waited for 30-45 min for secondary measurements. In each measurement, physical and physiological performances were evaluated.

Results: Total night sleep deprivation application resulted in a significant decrease in the salivary level of melatonin and impairment in static and dynamic balance, auditory reaction time, jump, upper body, lower body and handgrip strength performance $(p<0.05)$. The melatonin supplementation significantly decreased the salivary level of the melatonin $(p<0.05)$. The supplementation significantly improved the static and dynamic balance, but it significantly impaired the auditory reaction time $(p<0.05)$. The melatonin supplementation also significantly decreased the heart rate (HR) and systolic and diastolic blood pressure $(p<0.05)$.

Conclusion: The melatonin supplementation following total night sleep deprivation increased the salivary level of melatonin and reduced HR and blood pressure. Additionally, for athletes whose balance is the main factor of their success, melatonin may be beneficial following total night sleep deprivation.
\end{abstract}

Keywords: Ergogenic aids, sleep, performance, lactate, melatonin
Öz

Amaç: Bu çalışmada, eğitimli genç erkeklerde toplam gece uyku yoksunluğunu takiben melatonin desteğinin fiziksel ve fizyolojik performans üzerindeki etkilerinin değerlendirilmesi amaçlandı.

Gereç ve Yöntem: On eğitimli genç erkek $(23,4 \pm 1,71$ yaş, $23,96 \pm 1,63$ $\mathrm{kg} / \mathrm{m}^{2}$ ) dört gruba (1. ve 2. gruplar: Gece alışılmış uyku, 3. ve 4. gruplar: Toplam gece uyku yoksunluğu) katıldı. Daha sonra, çift kör tasarım kullanılarak, denekler iki melatonin takviyesi $(10 \mathrm{mg})$ ve plasebo grubuna ayrıldı. Denekler, uyku protokolünün uygulanmasıyla test edildi. Daha sonra takviyeyi tükettiler ve sekonder ölçümler için 30 ila 45 dakika beklediler. Her ölçümde fiziksel ve fizyolojik performanslar değerlendirildi.

Bulgular: Toplam gece uyku yoksunluğu uygulaması, melatonin tükürük düzeyinde anlamlı bir düşüşe ve statik ve dinamik denge, işitsel reaksiyon süresi, sıçrama, üst vücut, alt vücut ve el kavrama gücü performansında bozulma ile sonuçlandı $(p<0,05)$. Melatonin takviyesi, melatoninin tükrük seviyesini önemli ölçüde düşürdü $(p<0,05)$. Statik ve dinamik denge anlamlı olarak düzelti, ancak işitsel reaksiyon süresi takviye ile önemli ölçüde bozuldu $(p<0,05)$. Sistolik ve diyastolik kan basıncının yanı sıra kalp hızı $(\mathrm{KH})$ melatonin takviyesi ile önemli ölçüde düşüş gösterdi $(p<0,05)$.

Sonuç: Toplam gece uykusu yoksunluğunu takiben melatonin takviyesi, melatoninin tükrük seviyesini artırdı ve $\mathrm{KH}$ ve kan basıncını düşürdü. Ek olarak, dengesi başarılarının ana faktörü olan sporcular için melatonin, toplam gece uyku yoksunluğunu takiben faydalı olabilir.

Anahtar Kelimeler: Ergojenik yardımcılar, uyku, performans, laktat, melatonin 


\section{Introduction}

Melatonin (MEL) is a hormone secreted from the pineal gland during the night and has a significant role in the sleeping/ awakening cycle. MEL is associated with memory and regulates memory formation by affecting hippocampal neurons (1). Also, a possible relationship between MEL secreted from the pineal gland and exercise was expressed in some studies. With regard to this supplement in the field of sport, it is shown that the exercise could be beneficial.

Some other studies suggest that the exogenous MEL supplementation has ergogenic aid effects and may improve athletic performance, whereas the MEL supplementation can also have sleep aid because of its depressive effects on the central nervous system $(2,3)$. In addition, sleep deprivation (SD) affects the secretion of the MEL.

Sufficient sleep has a significant role in the biological functions of the body (4), and is one of the most important indicators that could help athletes to achieve peak performance. Since sleep has a direct relationship and interaction with performance, there is a need for improved sleep strategy, which is essential for better competition $(5,6)$.

Also, a piece of evidence confirmed this relationship and demonstrated that SD has negative effects on the athlete's performance (7). SD is the condition of having insufficient sleep (8). This problem generally occurs due to the jet lag, anxiety, stress, hotel bed, and noisy environment during the night before the competitions $(7,9)$. Therefore, these issues negatively influence the quality of the recommended 9 to10-hr sleep for athletes (7). Besides the above reasons, competition time is also one of the main reasons for SD. So that at the Rio 2016 Olympic Games, some competitions (swimming, beach volley, and track and field) were started at abnormal times (10 p.m. and midnight, based on the local time).

Apart from this, television interviews and doping tests are also some reasons for SD. All of these factors lead to SD and poor performance (10). In this regard, Martin and et al. (11) studied the diurnal variation of vertical perception and postural control after sleep and concluded that SD could have a negative effect on the balance and subsequent fall. Pallesen et al. (12) after investigating the effects of SD on soccer skills found that soccer skill is negatively affected by SD. In addition, after depriving the subjects of sleep, Reilley and Piercy (13) performed research on weight-lifting performance and observed that submaximal lifting tasks are worsened with SD.

The safe dose of supplementation has potential ability to modulate physical and physiological dysfunction associated with SD, but there is no available evidence about the effect of MEL on the physical and physiological performance following total night sleep deprivation (TSD). Therefore, this study was designed to determine whether the effects of the ergogenic aids of MEL could affect physical and physiological dysfunction due to TSD. On this basis and according to the literature, we hypothesized that MEL supplementation could affect physical and physiological performance following TSD in trained young males. For this purpose, we evaluated the effects of TSD on physical and physiological performance in trained young males.
In addition, we analyzed the effects of MEL supplementation on physical and physiological dysfunction due to TSD.

\section{Materials and Methods}

\section{Participants and anthropometric measurements}

Ten trained young males (age: $23.4 \pm 1.71 \mathrm{yr}$, height: $176 \pm 6.42$ $\mathrm{cm}$, weight: $74.28 \pm 6.69 \mathrm{~kg}$, body fat: $13.4 \pm 2.75 \%$, body mass index: $23.96 \pm 1.63 \mathrm{~kg} / \mathrm{m}^{2}$ ) from the University of Guilan (Faculty of Physical Education and Sport Sciences) with a history of regular training in the recent year (at least 3-4 days per week for an average of 2-hr training in a day) participated in the present study. The data, which are reported in Table 1, show the characteristics of the participants. Before the beginning of the research, all subjects were given information about experiment steps and probable risks, and the written consents were obtained from them. Finally, they were selected by applying entry/exit criteria:

- They were young, healthy, and practiced men.

- Although they were self-reported subjects, they were selected by medical examinations.

- They were non-smokers, did not consume caffeine or alcoholic beverages (which could enhance or compromise wakefulness), did not consume foodstuffs (which are effective in MEL hormone).

Before the assessments, the study protocol was approved by the ethical committee of Guilan University of Medical Sciences (IR. GUMS.REC.1397.137) and met the ethical standards.

\section{Experiments and protocol}

One week before the experiment, participants were familiarized with the experimental procedures to minimize the learning effect during the implementation of the protocol, and the initial measurements were done on the same day.

The participants were studied in four sessions as follows:

Sessions 1 and $2(n=10)$ : all participants had nightly habitual sleep (NS) (11-12 p.m. slept and 7-8 a.m. woke up) and were divided into placebo (PLA) and MEL group by crossover and double-blind designs.

Sessions 3 and 4: all attended subjects were TSD and divided into PLA and MEL group by crossover and double-blind designs. The experiment was performed in four sessions, and subjects were allowed to make a one-week recovery period between sessions. In each session, they were either asleep or deprived of sleep, and after implementing the sleep protocol, subjects were given a pre-test before taking the supplement. Then MEL was consumed $(10 \mathrm{mg}$ ) by participants. After that, we waited for 30

\begin{tabular}{|l|l|}
\hline Table 1. Characteristics of participants $(\mathrm{n}=10)$ \\
\hline Variable & Mean \pm SD \\
\hline Age $(\mathrm{yr})$ & $23.4 \pm 1.71$ \\
\hline Height $(\mathrm{cm})$ & $176 \pm 6.42$ \\
\hline Body weight $(\mathrm{kg})$ & $74.28 \pm 6.69$ \\
\hline Body fat $(\%)$ & $13.4 \pm 2.75$ \\
\hline BMl $\left(\mathrm{kg} \cdot \mathrm{m}^{-2}\right)$ & $23.96 \pm 1.63$ \\
\hline BMI: Body Mass index, SD: Standard deviation \\
\hline
\end{tabular}


to 45-min, and pre-test tests were repeated as a post-test phase [Running-based Anaerobic Sprint test (RAST) was only in the post-test]. The exact timing of the protocol in various stages is explained in Table 2.

All experiments and laboratory conditions as well as the room conditions (place of sleep control) were the same (temperature: $22{ }^{\circ} \mathrm{C}-24{ }^{\circ} \mathrm{C}$ and illumination: $150-200$ lux). In addition, when the subjects were deprived of sleep, they were allowed to read books, listen to music, or talk to each other, but they were not allowed to eat food or use caffeine or stimulants, but they were allowed to drink water.

Moreover, the mentioned items and conditions of the subjects were constantly controlled by the researcher. Participants in this study were students, and during the implementation of the research protocol, they ate similar nutrition from the university

\begin{tabular}{|c|c|}
\hline Time (hours) & Sessions \\
\hline $8: 00$ a.m & Breakfast \\
\hline 1:00 p.m & Lunch \\
\hline 9:00 p.m & Dinner \\
\hline $\begin{array}{l}\text { 11:00 p.m-12:00 a.m to } \\
\text { 7:00-8:00 a.m }\end{array}$ & $\begin{array}{l}\text { Sessions 1, 2: NS and sessions 3, 4: } \\
\text { TSD }\end{array}$ \\
\hline 8:15 a.m & Breakfast \\
\hline 9:30 a.m & Pre-test saliva \\
\hline 9:35 a.m & Warm-up \\
\hline 9:45-11:00 a.m & $\begin{array}{l}\text { Pre-test (respectively): } \\
\text { HR } \\
\text { Blood pressure } \\
\text { Static balance } \\
\text { Dynamic balance } \\
\text { ART } \\
\text { HG } \\
\text { Strength } \\
\text { Jump strength } \\
\text { Upper body strength } \\
\text { Lower body strength }\end{array}$ \\
\hline 11:00 a.m & Supplement \\
\hline $\begin{array}{l}11: 30-11: 45 \text { a.m to } \\
12: 30-12: 45 \text { p.m }\end{array}$ & $\begin{array}{l}\text { Post-test (Respectively): } \\
\text { HR } \\
\text { Blood pressure } \\
\text { Static balance } \\
\text { Dynamic balance } \\
\text { ART } \\
\text { HG } \\
\text { Strength } \\
\text { Jump strength } \\
\text { Upper body strength } \\
\text { Lower body strength } \\
\text { RAST }\end{array}$ \\
\hline $\begin{array}{l}\text { 12:38-12:53 p.m ( } 8 \text { minute } \\
\text { after the RAST test) }\end{array}$ & Post-test saliva \\
\hline \multicolumn{2}{|c|}{$\begin{array}{l}\text { NS: Nightly habitual sleep, TSD: Total night sleep deprivation, HR: Heart rate, } \\
\text { ART: Auditory reaction time, HG: Handgrip, RAST: Running-based Anaerobic } \\
\text { Sprint test }\end{array}$} \\
\hline
\end{tabular}

restaurant with an average of $2929.0 \pm 111.10 \mathrm{kcal}(27.5 \pm 2.91 \%$ of energy from fat, $16.0 \pm 2.21 \%$ protein, and $56.5 \pm 2.17 \%$ carbohydrates). Also, the subjects maintained regular physical activity during the sessions' intervals and avoided intense activity 48 hours before the experiment sessions; and all recommendations and instructions for physical activity, sleep, and diet were always reviewed.

The test items in this experiment were as follows:

- Jump strength by vertical jump test (Sargent jump) and by the Versus Tonic vertical jump machine (JPN PROD),

- Upper body, lower body, and handgrip (HG) strength, respectively by the bench press, squat, and Saehan digital hand dynamometer (KOR PROD),

- Static and dynamic balance by standing stork test and stability platform machine,

- Auditory reaction time (ART) by the reaction time machine (USA PROD),

- Arterial blood pressure by the Sphygmomanometer; heart rate (HR) and RAST were only considered in post-test and with the aim of affecting on lactate secretion,

- Salivary level of MEL was evaluated by the kits of IBL (GER PROD) company (intra-assay coefficients of variation of 6.1$10.8 \%$ and inter-assay coefficients of variation of $7.6-13.0 \%$ ),

- Salivary level of lactate was evaluated by the kits of ZellBio $\mathrm{GmbH}$ (GER PROD) company (intra-assay coefficients of variation of $<3.8 \%$ and inter-assay coefficients of variation of $<4.2 \%)$,

It is necessary to mention that the MEL hormone was evaluated by enzyme-linked immunosorbent assay (USA PROD: Biotech company model ELX 800) and lactate by Colorimetric method.

\section{Statistical Analysis}

The Shapiro-Wilk test was used to evaluate the normality of the data. Sessions data are presented as the mean and standard deviation. Data across intervention and all of the test sessions were analyzed by using two-way repeated measures ANOVA. A value of $p<0.05$ for all statistical analysis was considered.

\section{Results}

\section{Melatonin}

TSD led to a reduction in the level of MEL. By supplementation, a significant increasing difference was found between the pretest and post-test of the TSD $(p=0.002)$ and NS $(p=0.002)$ sessions, while there was no significant difference between the pre-test and post-test of the TSD $(p=0.248)$ and NS $(p=0.258)$ sessions in the PLA (Figure 1).

\section{Lactate}

TSD had no effect on the level of lactate. Lactate in both NS $(p=0.048)$ and TSD $(p=0.032)$ sessions increased by supplementation. It is also increased in both TSD $(p=0.003)$ and NS $(p=0.025)$ sessions of the PLA (Figure 2$)$.

\section{Heart rate}

TSD had no effect on HR. There was a significant decreasing difference in HR after supplementation in the NS $(p=0.049)$ and TSD ( $p=0.047)$ sessions; however, there was no significant 


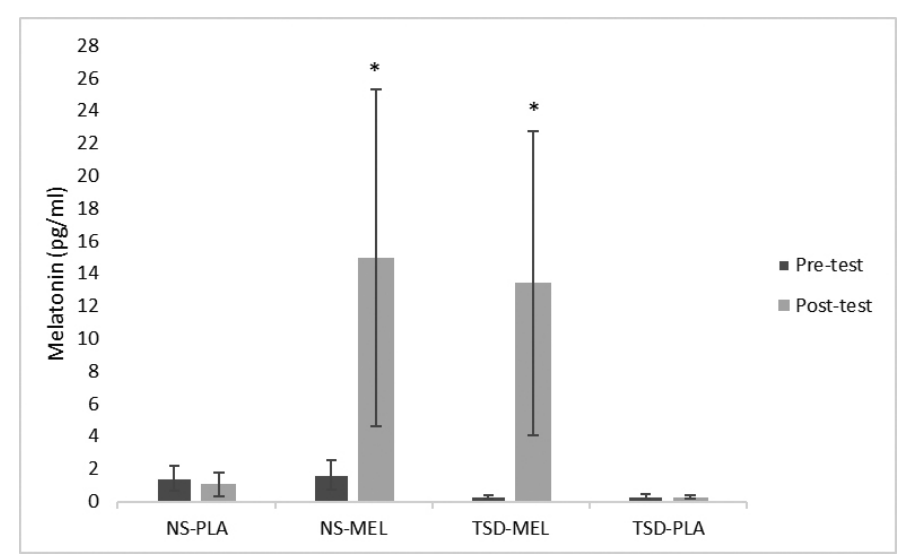

Figure 1. Changes in the salivary level of MEL

MEL: Melatonin, *: Significant difference compared to pre-test $(p<0.05)$

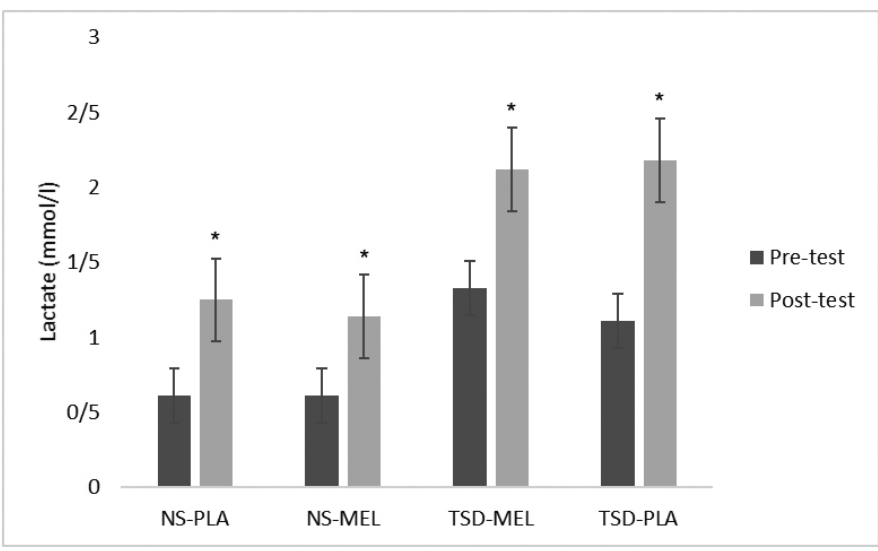

Figure 2. Changes in the salivary level of lactate

*: Significant difference compared to pre-test $(p<0.05)$

difference between pre-test and post-test in the TSD $(p=0.714)$ and NS ( $p=0.570)$ sessions in the PLA (Table 3$)$.

\section{Blood pressure}

TSD had no effect on diastolic blood pressure (DBP) and systolic blood pressure (SBP). There was a significant decreasing difference in DBP after supplementation in the NS $(p=0.020)$ and TSD $(p=0.003)$ sessions; however, there was no significant difference between pre-test and post-test in the TSD $(p=0.460)$ and NS ( $p=0.052)$ sessions in the PLA (Table 3 ).

Also, there was a significant decreasing difference in SBP after supplementation in the NS $(p=0.001)$ and TSD $(p=0.0001)$ sessions; however, there was no significant difference between pre-test and post-test of TSD $(p=0.602)$ and NS $(p=0.108)$ sessions in the PLA (Table 3).

\section{Strength}

TSD led to a reduction in upper body strength, lower body strength, HG strength, and jump strength. There was no significant difference in the pre-test and post-test of the upper body strength $(p=0.343)$, lower body strength $(p=1.0)$,
HG strength $(p=0.273)$, and jump strength $(p=0.893)$ by supplementation and NS conditions. Also, these results for upper body strength $(p=0.279)$, lower body strength $(p=0.726)$, HG strength $(p=0.642)$, and jump strength $(p=0.898)$ in the TSD condition are consistent with the results of NS condition. In addition, there was no significant difference in the PLA in both TSD and NS conditions ( $p>0.05$ ) (Table 3).

\section{Balance}

TSD led to a reduction in static and dynamic balance. Changes in the static and dynamic balance showed that a significant difference was found between pre-test and post-test by supplementation in the NS $(p=0.003)$ and TSD $(p=0.0001)$ sessions in the dynamic balance. In addition, similar changes were observed in both NS $(p=0.002)$ and TSD $(p=0.004)$ sessions in static balance, also balance time increased by supplementation. In the PLA, there was no significant difference in pre-test and post-test of dynamic balance in both TSD $(p=0.493)$ and NS $(p=0.798)$ conditions. Also, for static balance, in both TSD $(p=0.291)$ and NS $(p=0.871)$ conditions, the results were not significant (Table 3 ).

\section{Auditory reaction time}

TSD led to a reduction in ART. Changes in ART showed that by supplementation, there was a significant difference between the pre-test and post-test of the NS $(p=0.006)$ and TSD $(p=0.047)$ sessions, and ART was negatively affected by supplementation. However, there was no significant difference between the pretest and post-test of the TSD $(p=0.656)$ and NS $(p=0.803)$ sessions in the PLA (Table 3).

\section{Discussion}

Acute SD is common among modern societies (14), and in this case, there is no exception for elite athletes. Such deprivations could affect some physical and physiological functions of the body (5). Therefore, modulating the negative effects can be very important. In our research, acute TSD in some variables such as balance led to a negative effect, and in some other variables such as strength led to a neutral effect.

So, with the goal of impressing these effects, we used the MEL supplementation, which had an effect on physical and physiological performance based on some studies $(10,11,15,16)$. Moreover, at least in terms of our measurements, the MEL supplementation could have a positive effect on some variables. In line with the observations of other researches, we aimed to measure the negative effects of TSD, and then our goal was to evaluate the effects of the MEL supplementation on these effects.

Sleep has several biological pathways, from the neural cortical circuits to the heart $(17,18)$. In two states of sleep and awakening, there are some changes in the biological functions of the body, such as HR, arterial blood pressure, temperature, hormonal secretion, and immune function. The correction of the cardiovascular conditions seriously occurs during sleep and should be considered as a strong, bidirectional, and interconnection link between the cardiovascular system and sleep. Consequently, cardiovascular diseases could lead to sleep 
Khaleghi-Mamaghani et al.

Effects of Melatonin Supplementation Following Sleep Deprivation

\begin{tabular}{|c|c|c|c|c|c|}
\hline \multirow[t]{2}{*}{ Variable } & \multirow[t]{2}{*}{ Sleep } & \multicolumn{2}{|l|}{ Pla } & \multicolumn{2}{|l|}{ Mel } \\
\hline & & Pre-test & Post-test & Pre-test & Post-test \\
\hline \multirow{2}{*}{ HR (beat/min) } & NS & $60.20 \pm 5.75$ & $61.80 \pm 5.51$ & $63.20 \pm 11.52$ & $56.30 \pm 4.16^{*}$ \\
\hline & TSD & $62.30 \pm 5.92$ & $62.70 \pm 6.09$ & $63.10 \pm 5.50$ & $59.00 \pm 7.08^{8}$ \\
\hline \multirow{2}{*}{ DBP (mmg) } & NS & $76.5 \pm 6.25$ & $79.0 \pm 5.67$ & $76.0 \pm 7.74$ & $69.2 \pm 6.89^{*}$ \\
\hline & TSD & $80.3 \pm 5.35$ & $81.0 \pm 5.16$ & $80 \pm 5.27$ & $72.5 \pm 5.89^{\$}$ \\
\hline \multirow{2}{*}{ SBP (mmg) } & NS & $117.0 \pm 7.88$ & $121.5 \pm 6.25$ & $121.0 \pm 5.67$ & $110 \pm 6.23^{*}$ \\
\hline & TSD & $120.7 \pm 4.0$ & $121.5 \pm 5.29$ & $123.0 \pm 5.86$ & $111.0 \pm 6.99^{\$}$ \\
\hline \multirow{2}{*}{ ART (s) } & NS & $0.53 \pm 0.19$ & $0.55 \pm 0.16$ & $0.53 \pm 0.09$ & $1.02 \pm 0.43^{*}$ \\
\hline & TSD & $1.16 \pm 0.53$ & $1.09 \pm 0.43$ & $1.09 \pm 0.47$ & $1.52 \pm 0.60^{\$}$ \\
\hline \multirow{2}{*}{ Dynamic balance (s) } & NS & $8.39 \pm 2.89$ & $8.12 \pm 0.88$ & $8.57 \pm 2.39$ & $11.02 \pm 2.30^{*}$ \\
\hline & TSD & $5.13 \pm 1.07$ & $5.43 \pm 1.03$ & $5.35 \pm 1.07$ & $8.41 \pm 0.97^{\$}$ \\
\hline \multirow{2}{*}{ Static balance (s) } & NS & $9.96 \pm 2.47$ & $9.87 \pm 3.28$ & $10.19 \pm 2.97$ & $12.18 \pm 2.41^{*}$ \\
\hline & TSD & $6.83 \pm 0.81$ & $6.38 \pm 0.86$ & $8.02 \pm 1.85$ & $9.92 \pm 2.35^{\S}$ \\
\hline \multirow{2}{*}{ Jump strength (cm) } & NS & $40.0 \pm 6.66$ & $40.2 \pm 5.69$ & $39.7 \pm 7.60$ & $39.8 \pm 7.77$ \\
\hline & TSD & $33.7 \pm 6.34$ & $33.7 \pm 7.51$ & $34.9 \pm 8.92$ & $35.1 \pm 7.32$ \\
\hline \multirow{2}{*}{ HG (kg) } & NS & $47.1 \pm 7.20$ & $46.7 \pm 7.64$ & $46.9 \pm 7.03$ & $46.4 \pm 7.39$ \\
\hline & TSD & $41.6 \pm 6.09$ & $41.4 \pm 6.05$ & $41.8 \pm 7.03$ & $41.6 \pm 7.38$ \\
\hline \multirow{2}{*}{ Squat (kg) } & NS & $78.0 \pm 12.29$ & $77.5 \pm 12.74$ & $78.0 \pm 13.16$ & $78.0 \pm 12.51$ \\
\hline & TSD & $66.0 \pm 9.94$ & $67.5 \pm 10.34$ & $66.5 \pm 11.79$ & $67.0 \pm 10.59$ \\
\hline \multirow{2}{*}{ Bench press $(\mathrm{kg})$} & NS & \begin{tabular}{|l|}
$65.5 \pm 14.03$ \\
\end{tabular} & \begin{tabular}{|l|}
$66.5 \pm 15.64$ \\
\end{tabular} & $66.5 \pm 15.64$ & $67.0 \pm 15.12$ \\
\hline & TSD & $60.0 \pm 15.27$ & $59.5 \pm 14.42$ & $59.5 \pm 14.23$ & $58.0 \pm 13.16$ \\
\hline \multirow{2}{*}{ Anaerobic peak power (watts) } & NS & - & $532.3 \pm 127.89$ & - & $514.3 \pm 136.07$ \\
\hline & TSD & - & $484.4 \pm 80.24$ & - & $487.6 \pm 89.40$ \\
\hline \multirow{2}{*}{$\begin{array}{l}\text { Anaerobic minimum power } \\
\text { (watts) }\end{array}$} & NS & - & $273.6 \pm 89.13$ & - & $263.5 \pm 65.58$ \\
\hline & TSD & - & $278.0 \pm 75.78$ & - & $289.7 \pm 80.53$ \\
\hline \multirow{2}{*}{ Average power (watts) } & NS & - & $388.1 \pm 109.29$ & - & $376.8 \pm 96.77$ \\
\hline & TSD & - & $392.3 \pm 61.12$ & - & $373.7 \pm 86.78$ \\
\hline \multirow{2}{*}{ Fatigue index (watts/sec) } & NS & - & $6.92 \pm 2.92$ & - & $6.63 \pm 3.32$ \\
\hline & TSD & - & $5.54 \pm 2.09$ & - & $5.19 \pm 1.85$ \\
\hline \multicolumn{6}{|c|}{$\begin{array}{l}\text { *: Significant difference between pre-test and post-test on the MEL and PLA group NS }(p<0.05) \text {, s: Significant difference between pre-test and post-test on the MEL and } \\
\text { PLA group TSD ( }<<0.05) \text {, SD: Standard deviation, PLA: Placebo, MEL: Melatonin, NS: Nightly habitual sleep, TSD: Total night sleep deprivation, HR: Heart rate, DBP: } \\
\text { Diastolic blood pressure, SBP: Systolic blood pressure, ART: Auditory reaction time, HG: Handgrip }\end{array}$} \\
\hline
\end{tabular}

disorders, and also sleep problems could cause cardiovascular disorders (19).

According to the results of this study, there was no significant difference in HR, SBP, and DBP between session 1 with 3 and 4; and between session 2 with 3 and 4 (see section 2.2). In a study that examined the effects of SD on neural circulatory control, the results of the HR were consistent with our results (20). In addition, Sforza et al. (21) found similar results to our findings in examining the effects of SD.

In contrast, some contradictory results were also observed $(20,22)$. After examining all sections of these studies, we concluded that there is a substantial difference between the subjects' features/fitness. However, aside from this vast difference, we had some limitations. We did not measure the variables of catecholamines, sympathetic and parasympathetic system as well as the renin-angiotensin system. And also the time of TSD was one of the most critical factors, which led to these differences. In the present study, the effects of TSD were lower than other studies, and this is probably due to the fact that the SD time in the present study was lower. Moreover, this could suggest that in the future, other possible researches in this issue/topic may result in different TSD times.

In our study, HR is decreased by supplementation. Also, blood pressure showed a significant decrease by the supplementation. Therefore, the MEL supplementation in TSD conditions affects blood pressure, but this impact seems to be more effective on SBP rather than DBP. This result of our research is similar to the studies of Paulis and Šimko (15), Cagnacci et al. (23), and Atkinson et al. (24) that examined the effects of this supplement or the relationship of this hormone with $\mathrm{HR}$ and blood pressure 
$(15,23,24)$. Moreover, it even has been reported that a natural drop in blood pressure overnight may be due to an increase in MEL concentration (25).

It should be noted that MEL affects cardiac contractility (26). Also, MEL receptors have been discovered in the heart and have shown that MEL could reduce HR (27). Decrease of HR is associated with an increase in epithelial vasodilation and an increase in the susceptibility to $\mathrm{N}$-synthase inhibitors. This hypothesis is confirmed by observing an increase in systolic $\mathrm{Ca}^{+2}$ in endothelial cells that can lead to an increase in NO production by increasing the activity of NO-synthase, increasing the amount of cyclic GMP, and reducing the extracellular $\mathrm{Ca}^{+2}$ cells of the smooth muscle that is followed by vasodilation.

$\mathrm{N}$-acetylcysteine antioxidant reduces blood pressure, HR, and concentration of catecholamines at levels that are similar to MEL. However, reducing HR and blood pressure and improving baroreflex is associated with improved antioxidant capacity after MEL consumption. This antioxidant property of MEL shows the ability to reduce its sympathetic tone. MEL affects the cardiovascular system and is found in the blood vessels of melatonergic receptors. MEL reduces the contraction of the aortic ring by inhibiting phospholipase $\mathrm{C}$ on MT receptors (melatonergic receptors), or blocked alpha adrenoceptor. With regard to the mechanical performance of blood pressure, cardiac output, and peripheral resistance, MEL mechanism on blood pressure is similar to the HR as mentioned later (28).

By conforming to Souissi et al. (29) study, salivary lactate was not affected by TSD, and this is probably due to low TSD time. Supplementation could not cope with increasing lactate. Moreover, lactate significantly increased after RAST in all sessions, which is inconsistent with the results of Kaya et al. (30) study. This inconsistency could be due to the dosage and duration of consumption as well as the different subjects in the research. In addition, the short-term use of supplementation in this study is considerable, and thus researchers can examine the long-term effects in the future.

Our study showed that the response time for ART was disturbed because of TSD, which is consistent with the findings of Lingenfelser et al. (31) and Caldwell et al. (32), and it has been proven that psychological and mood-related behaviors can be much more affected (33). It is likely that the study of psychological effects on performance could also be an interesting research topic in the future.

In the case of SD, two factors can affect the psychological performance, especially the ART, the first factor is fatigue, and the second one is the initial awakening or the lack of paradoxical sleep. In this study, deprivation of sleep was acute, so the second factor has a greater effect. This type of sleep increases at the end of the night and is very important in the coordination of the circadian system (34). The frontal lobe of the brain is highly responsive to sleep (35), and with regard to the tasks of the frontal lobe that has special importance in the psychological acts (36), then as a result of acute TSD, response to the stimulus is compromised.

Subsequently, it was found that the supplement had a negative effect on ART, and recent reports also pointed out that consumption of MEL decreases temperature and processing of the body $(37,38)$, and as a result, due to the features of the hypothermia hormone, the processing speed of the brain decreases. However, controlling body temperature is one of the limitations of this research. In the future, researchers may investigate the effects of the MEL hypothermia on the ART.

In this study, the dynamic and static balance has been disturbed by TSD, similar to some other studies. However, there is some inconsistency with the results of some other researches. And SD time is the main reason for this inconsistency.

With prolonged SD, negative effects on balance will increase. However, there were also researchers who said that being awake during the night would slow down the processing speed of visual inputs during postural control, and the same researchers demonstrated that fatigue mentally referred to the loss of balance due to 24-hr SD (39).

Probably the loss of balance, in the long-term deprivation, is related to the fatigue, which is better to be investigated in the future regarding the effect of the TSD time on the balance, and factors that affect the balance.

However, in our study, the balance was improved by supplementation, which is consistent with the result of the Kamoun et al. (2) study, but has a contrast with the result of Fraschini et al. (16) research. The cause of the contradiction could refer to the supplementation time and supplementation distance to the test.

Regarding MEL, balance, and the reason for consensus, in the outer region of the molecular layer of the cerebellum, there is a known receptor, and it seems that there is a high density of MEL receptors. As it was reported, the effect of MEL on the vestibular reflexes may be mediated by cerebellum receptors (16).

Regarding strength and Jump strength, this study showed that TSD could disrupt these variables; however, this result is in contrast to the results of other researchers. They observed that following acute SD, there is no negative effect on the strength and Jump strength $(24,40)$. In our research, the subjects were trained males, but in their researches, participants were athletes. Therefore, the level of the subjects' fitness could be the main reason for this contrast. Probably due to the level of the physical fitness of trained males, compared to athletes, they could not cope with the effects of TSD.

Of course, the number of participated subjects in the study is important and can have significant effects on the research outcome. Therefore, the study of TSD effects at different levels of fitness can be an important research challenge in the future. There was no significant change in strength and Jump strength with supplementation. It is known that MEL mediates two objecting responses in vascular smooth muscle cells that is a concentration-dependent procedure. MEL at low concentrations enhances contractions, although it should be noted that it has a negative effect on higher concentrations (25).

However, MEL prevents the increase of body temperature and its beneficial effects over the course of the day due to the hypothermic property, and also, body temperature does not increase throughout the day and cannot be considered as a warm-up. And consequently, MEL prevents the increase 
of muscle viscosity, and also it reduces the velocity of nerve conduction as well as a range of motions. As a result, strength performance does not improve (38).

Similar to some reports, the salivary level of MEL was decreased by TSD. Therefore, there is always a relationship between sleep and secretion of MEL (9).

\section{Conclusion}

The present study indicates that MEL reduces cardiovascular responses in TSD situations, and MEL has a useful effect in the sports that balance is a major factor. However, it should be noted that ART delayed, so athletes who need vigilant body should be conscious about using it. In the next research, we will focus on the effects of different doses at different times of day or night with various measured variables.

\section{Acknowledgements}

The authors would like to thank the participants for their dedication and effort throughout the study.

\section{Ethics}

Ethics Committee Approval: It was taken by Ethical Committee of Guilan University of Medical Sciences (IR.GUMS. REC.1397.137).

Informed Consent: Informed consent statement was in adherence with the human subject's Guidelines of Research Center.

Peer-review: Internally peer-reviewed.

\section{Authorship Contributions}

Surgical and Medical Practices: E.K.M., F.R.N., H.A., Concept: E.K.M., F.R.N., H.A., Design: E.K.M., F.R.N., H.A., Data Collection or Processing: E.K.M., F.R.N., H.A., Analysis or Interpretation: E.K.M., F.R.N., H.A., Literature Search: E.K.M., F.R.N., H.A., Writing: E.K.M., F.R.N., H.A.

Conflict of Interest: No conflict of interest was declared by the authors.

Financial Disclosure: The authors declared that this study received no financial support.

\section{References}

1. Emet M, Ozcan H, Yayla M, Halici Z, Hacimuftuoglu A. A review of melatonin, its receptors and drugs. The Eurasian J Med 2016;48:135-41.

2. Kamoun A, Yahia A, Ksentini H, Ghroubi S, Elleuch MH. Effect of nocturnal ingestion of melatonin on the static and dynamic balance in the elderly. Ann Phys Rehabil Med 2017;60:e52-3. doi: 10.1016/j. rehab.2017.07.199.

3. Kaya O, Kilic M, Celik I, Baltaci AK, Mogulkoc R. Effect of melatonin supplementation on plasma glucose and liver glycogen levels in rats subjected to acute swimming exercise. Pak J Pharm Sci 2010;23:241-4.

4. Halson SL. Sleep and the elite athlete. Sports Sci 2013;26:1-4.

5. Arazi H, Mehrabani J, Irandoost M, Khaleghimamaghani E. Effects of overnight sleep deprivation on appetite and physical performance in elite female soccer players. J Turk Sleep Med 2019;6:93-7.

6. Fox JL, Scanlan AT, Stanton R, Sargent C. Insufficient sleep in young athletes? Causes, consequences, and potential treatments. Sports Med 2020;50:461-70.
7. Bonnar D, Bartel K, Kakoschke N, Lang C. Sleep interventions designed to improve athletic performance and recovery: a systematic review of current approaches. Sports Med 2018;48:683-703.

8. Mc Donald C, Moore J, Mclntyre A, Carmody K, Donne B. Acute effects of 24-h sleep deprivation on salivary cortisol and testosterone concentrations and testosterone to cortisol ratio following supplementation with caffeine or placebo. Int J Exerc Sci 2017;10:108.

9. Kölling S, Duffield R, Erlacher D, Venter R, Halson SL. Sleep-related issues for recovery and performance in athletes. Int J Sports Physiol Perform 2019;14:144-8.

10. Rosa JP, Silva A, Rodrigues DF, Simim MA, Narciso FV, Tufik S, Bichara JJ, Pereira SR, Da Silva SC, de Mello MT. Effect of bright light therapy on delayed sleep/wake cycle and reaction time of athletes participating in the Rio 2016 Olympic Games. Chronobiol Int 2018;35:1095-103.

11. Martin T, Gauthier A, Ying Z, Benguigui N, Moussay S, Bulla J, Davenne D, Bessot N. Effect of sleep deprivation on diurnal variation of vertical perception and postural control. J Appl Physiol 2018;125:167-74.

12. Pallesen S, Gundersen HS, Kristoffersen M, Bjorvatn B, Thun E, Harris A. The effects of sleep deprivation on soccer skills. Percept Mot Skills 2017;124:812-29.

13. Reilly T, Piercy M. The effect of partial sleep deprivation on weightlifting performance. Ergonomics 1994;37:107-15.

14. Ackermann K, Plomp R, Lao O, Middleton B, Revell VL, Skene D], Kayser M. Effect of sleep deprivation on rhythms of clock gene expression and melatonin in humans. Chronobiol Int 2013;30:901-9.

15. Paulis L, Šimko F. Blood pressure modulation and cardiovascular protection by melatonin: potential mechanisms behind. Physiol Res 2007; 56 .

16. Fraschini F, Cesarani A, Alpini D, Esposti D, Stankov BM. Melatonin influences human balance. Biol Signals Recept 1999;8:111-9.

17. Tononi G, Cirelli C. Sleep function and synaptic homeostasis. Sleep Med Rev 2006; 10:49-62.

18. Saper CB, Scammell TE, Lu J. Hypothalamic regulation of sleep and circadian rhythms. Nature 2005;437:1257-63.

19. Tobaldini E, Costantino G, Solbiati M, Cogliati C, Kara T, Nobili L, Montano N. Sleep, sleep deprivation, autonomic nervous system and cardiovascular diseases. Neurosci Biobehav Rev 2017;74:321-9.

20. Kato M, Phillips BG, Sigurdsson G, Narkiewicz K, Pesek CA, Somers VK. Effects of sleep deprivation on neural circulatory control. Hypertension. 2000;35:1173-5.

21. Sforza E, Chapotot F, Lavoie S, Roche F, Pigeau R, Buguet A. Heart rate activation during spontaneous arousals from sleep: effect of sleep deprivation. Clin Neurophysiol 2004;115:2442-51.

22. Gangwisch JE, Heymsfield SB, Boden-Albala B, Buijs RM, Kreier F, Pickering TG, Rundle AG, Zammit GK, Malaspina D. Short sleep duration as a risk factor for hypertension: analyses of the first National Health and Nutrition Examination Survey. Hypertension 2006;47:833-9.

23. Cagnacci A, Arangino S, Angiolucci M, Maschio E, Longu G, Metis GB. Potentially beneficial cardiovascular effects of melatonin administration in women. J Pineal Res 1997;22:16-9.

24. Atkinson $G$, Jones $\mathrm{H}$, Edwards BJ, Waterhouse JM. Effects of daytime ingestion of melatonin on short-term athletic performance. Ergonomics 2005;48:1512-22.

25. Baker J, Kimpinski K. Role of melatonin in blood pressure regulation: An adjunct anti-hypertensive agent. Clin Exp Pharmacol Physiol 2018; 45:755-66.

26. Girouard H, Denault C, Chulak C, Champlain JD. Treatment by $\mathrm{N}$-acetylcysteine and melatonin increases cardiac baroreflex and improves antioxidant reserve. Am J Hypertens 2004;17:947-54. 
27. Reiter RJ. The melatonin rhythm: both a clock and a calendar. Experientia 1993;49:654-64.

28. McLellan TM, Gannon GA, Zamecnik J, Gil V, Brown GM. Low doses of melatonin and diurnal effects on thermoregulation and tolerance to uncompensable heat stress. J Appl Physiol (1985) 1999;87:308-16.

29. Souissi N, Sesboüé B, Gauthier A, Larue J, Davenne D. Effects of one night's sleep deprivation on anaerobic performance the following day. Eur J Appl Physiol 2003;89:359-66.

30. Kaya O, Gokdemir K, Kilic M, Baltaci AK. Melatonin supplementation to rats subjected to acute swimming exercise: Its effect on plasma lactate levels and relation with zinc. Neuro Endocrinol Lett 2006;27:263-6.

31. Lingenfelser TH, Kaschel $R$, Weber $A$, Zaiser-Kaschel $H$, Jakober $B$, Küper J. Young hospital doctors after night duty: their task-specific cognitive status and emotional condition. Med Educ 1994;28:566-72.

32. Caldwell JA, Prazinko B, Caldwell JL. Body posture affects electroencephalographic activity and psychomotor vigilance task performance in sleep-deprived subjects. Clin Neurophysiol 2003;114:23-31.

33. Davenne D. Sleep of athletes-problems and possible solutions. Biol Rhythm Res 2009;40:45-52.
34. Jarraya $S$, Jarraya $M$, Chtourou $H$, Souissi N. Effect of time of day and partial sleep deprivation on the reaction time and the attentional capacities of the handball goalkeeper. Biol Rhythm Res 2014;45:183-91.

35. Taheri M, Arabameri E. The effect of sleep deprivation on choice reaction time and anaerobic power of college student athletes. Asian J Sports Med 2012;3:15-20.

36. Jones K, Harrison Y. Frontal lobe function, sleep loss and fragmented sleep. Sleep Med Rev 2001;5:463-75.

37. Slotten HA, Krekling S. Does melatonin have an effect on cognitive performance? Psychoneuroendocrinology 1996;21:673-80.

38. Ghattassi K, Hammouda O, Graja A, Boudhina N, Chtourou H, Hadhri S, Driss T, Souissi N. Morning melatonin ingestion and diurnal variation of short-term maximal performances in soccer players. Physiol Int 2016;103:94-104.

39. Ma J, Yao YJ, Ma RM, Li JQ, Wang T, Li XJ, Han WQ, Hu WD, Zhang ZM. Effects of sleep deprivation on human postural control, subjective fatigue assessment and psychomotor performance. J Int Med Res 2009;37:1311-20.

40. Scheer FA. Melatonin, sleep, and circadian rhythms. Sleep Med Rev 2005;9:5-9. 